ISSN: 2451-1846

DOI: http://dx.doi.org/10.21784/IwP.2016.004

Maria Borowicz ${ }^{1}$, Mariola Rybka ${ }^{2}$

1 Poradnia Zdrowia Psychicznego przy Niepublicznym Zakładzie Opieki Zdrowotnej

"Lekarze Rodzinni" w Lipnie

2 Szpital Lipno Spółka z o.o.

\title{
Wybrane aspekty jakości życia pacjentów z depresją
}

\section{Selected aspects of quality of life of patients with depression}

\section{Streszczenie:}

Wstęp. Depresja jest jedną najpoważniejszych chorób cywilizacyjnych ostatnich lat. $\mathrm{W}$ obrazie klinicznym depresji, dominuje przede wszystkim obniżenie nastroju, odczuwane przez pacjentów jako stan przygnębienia, rezygnacji, smutku. Jakość życia w perspektywie nauk medycznych koncentruje się na zjawiskach zdrowia i choroby. Postęp w medycynie wydłużył czas życia pacjentów z różnymi chorobami, ale nie stał się wystarczającym miernikiem skuteczności leczenia. Poprawa jakości wydłużonego życia jest więc ważnym wyzwaniem dla współczesnej medycyny.

Cel. Celem pracy jest analiza aspektów jakości życia chorych na depresję w zależności od wybranych czynników demograficznych.

Materiał i metody. Badania przeprowadzono wśród pacjentów poradni zdrowia psychicznego. Zastosowano metodę sondażu diagnostycznego. W badaniach wykorzystano skróconą wersję GDS, skalę WHOQOL-Bref 
a także kwestionariusz ankiety własnej konstrukcji. Wyniki poddano analizie statystycznej.

Wyniki. Wśród badanych dominującą grupę stanowiły kobiety oraz osoby w wieku 46 do 70 lat. Większość pacjentów mieszkała na wsi i posiadała współmałżonka. Najliczniejszą grupę wśród badanych stanowiły osoby z wykształceniem średnim. Wyniki badań wskazują na istotne różnice w ocenie domen jakości życia z uwagi na płeć pacjentów.

Wnioski: Wśród osób z rozpoznaną depresją kobiety istotnie lepiej niż mężczyźni oceniają dziedziny jakości życia. Wiek nie determinuje istotnie oceny jakości życia przez chorych na depresję.

\begin{abstract}
:
Introduction. Depression is one of the most serious diseases of civilization in recent years.The clinical picture of depression, dominated primarily depressed mood, perceived by patients as a state of depression, resignation, sadness. Quality of life in the perspective of medical science focuses on the phenomena of health and disease. Progress in medicine has extended survival time for patients with various diseases, but there has to be a sufficient measure of efficacy. Improving the quality of life prolongation is therefore an important challenge for modern medicine.
\end{abstract}

Aim. The aim of the study is to analyze aspects of the quality of life of patients with depression, depending on the selected demographic factors

Material and methods. The study was conducted among patients mental health. The method of diagnostic survey. The study used a shortened version of the GDS, scale WHOQOL-Bref and a questionnaire survey of his own design. The results were statistically analyzed.

Results. Among the respondents, the dominant group were women and people aged 46 to 70 years. Most patients lived in the countryside and had a pouse. The largest group among the respondents were people with secondary education. The results show significant differences in the quality of life assessment domains on sex of patients.

Conclusions. Among those diagnosed with depression significantly more women than men evaluate the areas of quality of life. Age does not determine significant quality of life for patients with depression.

Słowa kluczowe: jakość życia, depresja, pacjent 
Keywords: quality of life, depression, the patient

\section{Wstęp}

Depresja jest jedną z najpoważniejszych chorób cywilizacyjnych ostatnich lat. W jej obrazie klinicznym, dominuje przede wszystkim obniżenie nastroju, odczuwane przez pacjentów jako stan przygnębienia, rezygnacji, smutku. Chorzy nie są w stanie przeżywać szczęścia, satysfakcji, radości. U cierpiących na depresję następuje również osłabienie tempa procesów psychicznych. Przejawia się ono spowolnieniem myślenia, zaburzeniami pamięci, koncentracji i uwagi oraz problemami z podejmowaniem decyzji. Może pojawić się również spowolnienie ruchów lokomocyjnych, aż do całkowitego zahamowania ruchowego. Zaburzeniom psychomotorycznym towarzyszy uczucie zmęczenia i znużenia, a u niektórych chorych niepokoju ruchowego i pobudzenia $[1,2]$.

Depresja może objawiać się również występowaniem u chorych zaburzeń rytmów biologicznych. Szczególną wagę dla diagnozy i terapii tej choroby mają zaburzenia rytmu snu i czuwania. Ważną cechą depresji jest lęk o zmiennym nasileniu, jak również poczucie zagrożenia. Chorobie towarzyszą także depresyjne zaburzenia myślenia w postaci negatywnej oceny własnej osoby jako bezwartościowej będącej obciążeniem dla bliskich. Niska samoocena wiąże się często z ogromnym poczuciem winy, postrzeganiem otoczenia za nieprzyjazne i niebezpieczne. Przyszłość traktowana jest jako pasmo niekończącego się cierpienia i nieszczęść co wywołuje poczucie beznadziejności. W konsekwencji, chory izoluje się od świata, stara się unikać towarzystwa innych ludzi, zrywa bliskie relacje interpersonalne co powoduje zanik aktywności zawodowej i społecznej. Krytycyzm w stosunku do siebie i swojej choroby sprawia, że jeszcze bardziej dotkliwie chory przeżywa własną bezradność [3].

Depresja jest chorobą o złożonej i wieloczynnikowej etiologii. Może mieć ona uwarunkowania psychologiczne, biologiczne lub społeczne. Przeprowadzone w ostatnim dziesięcioleciu badania w dużych 
reprezentatywnych populacjach wskazują, że rozpowszechnienie zaburzeń depresyjnych jest duże. Przyczyny depresji są wyjątkowo złożone i jest wśród nich wiele czynników o różnym nasileniu, a proces prowadzący do depresji jest wieloletni. We współczesnej psychiatrii metodą leczenia depresji jest kompleksowa terapia z zastosowaniem farmakoterapii, elektrowstrząsów, fototerapii oraz psychoterapii $[4,5]$.

Wieloletni przebieg choroby $\mathrm{z}$ okresami remisji i zaostrzeń wpływa niekorzystnie na stan zdrowia chorego i jakość jego życia. Światowa Organizacja Zdrowia przedstawia jakość życia jako osobiste postrzeganie przez jednostkę swojej pozycji życiowej w kontekście kulturowym i systemu wartości w jakich żyje oraz w odniesieniu do stawianych celów, oczekiwań, wzorców i obaw. Zdaniem jednego z prekursorów analiz związanych z jakością życia, A. Campbella, pojęcie jakości życia należy definiować $\mathrm{z}$ uwzględnieniem stopnia satysfakcji z życia rodzinnego, zawodowego, stosunków międzysąsiedzkich, relacji towarzyskich, stanu zdrowia, sposobu spędzania wolnego czasu, zdobytego wykształcenia, wykonywanej profesji. Czynniki wyróżnione przez A. Campbella, które mają stanowić o wysokiej bądź niskiej jakości życia można usytuować w kategorii potrzeb. Jakość życia, jest pojęciem interdyscyplinarnym. Zagadnieniem tym zajmują się badacze z zakresu medycyny, socjologii, filozofii, psychologii oraz ekonomii społecznej [6,7].

Jakość życia w perspektywie nauk medycznych, koncentruje się na zjawiskach zdrowia i choroby. Nie opracowano jednak dotąd jednolitej definicji przyjmowanej na gruncie różnych medycznych subdyscyplin. Jedną z prób sformułowania jednolitej definicji jakości życia, uwarunkowanej stanem zdrowia podjął się m.in. Schipper wraz z zespołem naukowym. Definicja jakości życia uwarunkowana stanem zdrowia uwzględnia cztery podstawowe aspekty funkcjonowania pacjenta czyli stan fizyczny, stan psychiczny, sytuację społeczną i ekonomiczną. oraz doznania somatyczne. Postęp w medycynie, wydłużył czas życia pacjentów z różnymi chorobami, ale nie stał się wy- 
starczającym miernikiem skuteczności leczenia. Poprawa jakości wydłużonego życia jest więc ważnym wyzwaniem dla współczesnej medycyny $[8,9]$.

Celem pracy jest analiza aspektów jakości życia chorych na depresję w zależności od wybranych zmiennych demograficznych.

\section{Materiał i metody}

Badania zostały przeprowadzone wśród pacjentów w Poradni Zdrowia Psychicznego przy Niepublicznym Zakładzie Opieki Zdrowotnej "Lekarze Rodzinni" w Lipnie. Badaniami objęto 70 osób w wieku od 25 do 70 lat. Wśród badanych większość stanowiły kobiety (73\%). Ponad polowa badanych osób zamieszkiwała tereny wiejskie (53\%). Pod względem stanu cywilnego dominującą grupę stanowy osoby pozostające w związku (60\%). Najliczniejszą grupą wśród badanych były osoby z wykształceniem średnim (41\%).

Dla wykonania badań zastosowano metodę sondażu diagnostycznego z wykorzystaniem skróconej wersji Geriatrycznej Skali oceny Depresji (GDS) oraz skalę WHOQOL-Bref, a także kwestionariusz ankiety własnej konstrukcji.

W celu zbadania zależności statystycznych między zmiennymi zastosowano Test t-Studenta, Test U-Manna-Whitney'a, Test Kruskala-Wallisa, a także Test niezależności chi-kwadrat Persona.

\section{Wyniki}

Większość badanych osób była w wieku od 46 do 70 lat (60\%). Osoby w wieku od 25 do 45 lat stanowiły 40\% badanych. Wśród badanych osób 53\% zamieszkiwało tereny wiejskie, natomiast $47 \%$ to mieszkańcy miasta. $\mathrm{W}$ badanej próbie większość stanowiły osoby zamężne/żonate (60\%). Osoby nie pozostające w stałym związku stanowiły $17 \%$ badanych, wdowy/wdowcy stanowili 14\% badanych, natomiast osoby rozwiedzione $9 \%$ badanych. Najliczniejszą grupą wśród badanych były osoby z wykształceniem średnim (41\%).Osoby posiadające wykształcenie podstawowe stanowiły $29 \%$ badanych, 
wykształcenie zawodowe posiadało $20 \%$, natomiast wykształcenie wyższe 10\% badanych. Ponad połowa respondentów (53\%) zamieszkiwała tereny wiejskie, natomiast $47 \%$ mieszkało w miastach. Najliczniejszą grupę wśród badanych stanowiły osoby z wykształceniem średnim (41\%). Osoby posiadające wykształcenie podstawowe stanowiły $29 \%$ badanych, wykształcenie zawodowe - 20\%, natomiast wykształcenie wyższe - 10\% badanych.

Wśród badanych osób 59\% zadeklarowało, że jest aktywna zawodowo, natomiast $41 \%$, że nie pracuje zawodowo.

W celu sprawdzenia, czy kobiety różnią się od mężczyzn pod względem oceny jakości życia, przeprowadzono analizę testem tStudenta dla prób niezależnych, co przedstawia tabela 1.

Tabela 1. Płeć a dziedziny jakości życia badanych

\begin{tabular}{|c|c|c|c|c|c|}
\hline $\begin{array}{c}\text { Dziedziny jako- } \\
\text { ści życia }\end{array}$ & Płeć & Średnia & $\begin{array}{c}\text { Odchylenie } \\
\text { standardowe }\end{array}$ & $\begin{array}{l}\text { Wynik } \\
\text { testu t }\end{array}$ & $\begin{array}{c}\text { Poziom } \\
\text { istotności }\end{array}$ \\
\hline \multirow{2}{*}{ Dziedzina fizyczna } & Kobieta & 13,07 & 2,09 & \multirow{2}{*}{4,39} & \multirow{2}{*}{$<0,001$} \\
\hline & Mężczyzna & 10,59 & 2,14 & & \\
\hline \multirow{2}{*}{$\begin{array}{l}\text { Dziedzina psycho- } \\
\text { logiczna }\end{array}$} & Kobieta & 11,39 & 2,62 & \multirow{2}{*}{2,61} & \multirow{2}{*}{0,011} \\
\hline & Mężczyzna & 9,58 & 2,45 & & \\
\hline \multirow{2}{*}{ Relacje społeczne } & Kobieta & 12,93 & 3,18 & \multirow{2}{*}{1,95} & \multirow{2}{*}{0,055} \\
\hline & Mężczyzna & 11,30 & 2,89 & & \\
\hline \multirow{2}{*}{ Środowisko } & Kobieta & 12,62 & 2,14 & \multirow{2}{*}{2,20} & \multirow{2}{*}{0,031} \\
\hline & Mężczyzna & 11,34 & 2,25 & & \\
\hline
\end{tabular}

Źródło: opracowanie własne.

Analiza testem t-Studenta dla prób niezależnych wykazała istotne statystycznie różnice wskazujące na to, że kobiety wyżej oceniają dziedziny jakości życia w sferze fizycznej, psychologicznej i środowiskowej niż mężczyźni. Jedynie w zakresie relacji społecznych oceny nie różniły się istotnie w zależności od płci pacjentów.

W celu sprawdzenia, czy wśród osób z rozpoznaną depresją kobiety różnią się od mężczyzn pod względem oceny domen jakości 
życia, przeprowadzono analizę testem U Manna-Whitneya, co przedstawia tabela 2.

Tabela 2. Płeć a dziedziny jakości życia badanych z rozpoznaną depresją

\begin{tabular}{|c|c|c|c|c|c|}
\hline $\begin{array}{c}\text { Dziedziny jakości } \\
\text { życia }\end{array}$ & Płeć & Średnia & $\begin{array}{c}\text { Odchylenie } \\
\text { standardowe }\end{array}$ & $\begin{array}{c}\text { Wynik } \\
\text { testu U } \\
\text { M-W }\end{array}$ & $\begin{array}{l}\text { Poziom } \\
\text { istotności }\end{array}$ \\
\hline \multirow{2}{*}{ Dziedzina fizyczna } & Kobieta & 12,93 & 2,06 & \multirow{2}{*}{3,97} & \multirow{2}{*}{$<0,001$} \\
\hline & Mężczyzna & 10,14 & 1,91 & & \\
\hline \multirow{2}{*}{$\begin{array}{l}\text { Dziedzina psycho- } \\
\text { logiczna }\end{array}$} & Kobieta & 11,36 & 2,52 & \multirow{2}{*}{2,70} & \multirow{2}{*}{0,007} \\
\hline & Mężczyzna & 9,37 & 2,52 & & \\
\hline \multirow{2}{*}{ Relacje społeczne } & Kobieta & 12,80 & 3,24 & \multirow{2}{*}{2,19} & \multirow{2}{*}{0,029} \\
\hline & Mężczyzna & 10,83 & 2,83 & & \\
\hline \multirow{2}{*}{ Środowisko } & Kobieta & 12,45 & 2,12 & \multirow{2}{*}{1,77} & \multirow{2}{*}{0,077} \\
\hline & Mężczyzna & 11,38 & 2,31 & & \\
\hline
\end{tabular}

Źródło: opracowanie własne.

Analiza testem U Manna-Whitneya wykazała istotne statystycznie różnice wskazujące na to, że wśród osób z rozpoznaną depresją to kobiety istotnie lepiej oceniały dziedziny jakości życia w sferze fizycznej, psychologicznej i relacji społecznych niż mężczyźni. Jedynie w zakresie domeny: Środowisko oceny nie różniły się istotnie w zależności od płci pacjentów.

Tabela 3 prezentuje różnice $\mathrm{w}$ ocenie domen jakości życia w zależności od wieku pacjentów, uzyskane w ramach analizy wyników badania testem $\mathrm{t}$-Studenta dla prób niezależnych.

Tabela 3. Wiek a dziedziny jakości życia badanych.

\begin{tabular}{|c|c|c|c|c|c|}
\hline $\begin{array}{c}\text { Dziedziny jakości } \\
\text { życia }\end{array}$ & Wiek & Średnia & $\begin{array}{c}\text { Odchylenie } \\
\text { standardowe }\end{array}$ & $\begin{array}{c}\text { Wynik } \\
\text { testu t }\end{array}$ & $\begin{array}{c}\text { Poziom } \\
\text { istotności }\end{array}$ \\
\hline
\end{tabular}




\begin{tabular}{|c|c|c|c|c|c|}
\hline \multirow{3}{*}{ Dziedzina fizyczna } & $25-45$ lat & 12,62 & 2,55 & \multirow{3}{*}{0,65} & \multirow{3}{*}{0,517} \\
\hline & & & & & \\
\hline & 46-70 lat & 12,24 & 2,25 & & \\
\hline \multirow{3}{*}{$\begin{array}{l}\text { Dziedzina } \\
\text { psychologiczna }\end{array}$} & $25-45$ lat & 10,26 & 2,63 & \multirow{3}{*}{1,63} & \multirow{3}{*}{0,107} \\
\hline & & & & & \\
\hline & 46-70 lat & 11,32 & 2,67 & & \\
\hline \multirow{2}{*}{ Relacje społeczne } & 25-45 lat & 12,12 & 3,41 & \multirow{2}{*}{0,79} & \multirow{2}{*}{0,433} \\
\hline & 46-70 lat & 12,73 & 3,01 & & \\
\hline \multirow{2}{*}{ Środowisko } & 25-45 lat & 11,96 & 2,23 & \multirow{2}{*}{0,98} & \multirow{2}{*}{0,332} \\
\hline & $46-70$ lat & 12,49 & 2,23 & & \\
\hline
\end{tabular}

Źródło: opracowanie własne.

Analiza testem t-Studenta dla prób niezależnych nie wykazała istotnych statystycznie różnic $w$ ocenie dziedzin jakości życia ze względu na wiek respondentów. Oznacza to, że osoby w wieku 25 do 45 lat nie różnią się istotnie w ocenach domen jakości życia od pacjentów w wieku 46 do 70 lat. Niemniej jednak najmłodsi respondenci dokonywali najniższej oceny wśród respondentów w zakresie dziedziny psychologicznej.

\section{Dyskusja}

Depresja to jeden z najpoważniejszych problemów zdrowotnych na świecie. Według Światowej Organizacji Zdrowia, objawia sie smutkiem, utratą zainteresowań i przyjemności, poczuciem winy, niską samooceną, zaburzeniami snu i apetytu, uczuciem osłabienia i zaburzeniami koncentracji. P. Łoza i T. Parnowski wskazują, że depresja znacząco wpływa na jakość życia pacjentów i ich zdolność funkcjonowania w każdym obszarze życia, zarówno społecznym jak i zawodowym [4]. W przedstawionej pracy powyższa teza znalazła częściowe potwierdzenie, wskazując na pewne różnice w ocenach domen jakości życia z uwagi na płeć chorych. 
W dobie ustawicznego rozwoju nauk medycznych stwarzane są coraz większe możliwości leczenia oraz sukcesywnego wydłużania życia pacjentów. Subiektywna ocena stanu zdrowia ma w ostatnich latach coraz większe znaczenie dla kształtowania jakości życia, szczególnie osób z przewlekłymi zaburzeniami w stanie zdrowia.

J. Trzebiatowski wskazuje, że jakość życia w perspektywie nauk medycznych, koncentruje się na zjawiskach zdrowia i choroby [7]. Z kolei M. Steiner i współautorzy podkreślają, że z pojęciem jakości życia, wiąże się jego ocena, czyli obraz położenia życiowego pacjenta w pewnym okresie, ujmowana subiektywnie i obiektywnie, w charakterze wielowymiarowym [6].

A. Trojanowska podaje, że w ujęciu medycznym jakość życia związana jest ściśle fizycznymi, psychicznymi i społecznymi dziedzinami zdrowia [7]. Prowadzenie badań nad jakością życia jest przejawem troski o dobro pacjenta oraz wyrazem zaangażowania ludzi wielu zawodów medycznych i niemedycznych. Celem tych badań jest ocena stanu zdrowia chorego oraz funkcjonowanie w ważnych dla niego dziedzinach [7].

Dla przeciętnego człowieka jakość życia wiąże się nierozerwalnie ze zdrowiem, udanym życiem rodzinnym, poczuciem własnej wartości, dobrymi kontaktami społecznymi, umiejętnością radzenia sobie w sytuacjach trudnych, poczuciem bezpieczeństwa. D. Kochman podaje w swojej pracy, że jakość życia jest zdeterminowana wszystkimi czynnikami, których zaspokojenie pozwala jednostce na poczucie spełnienia i motywację do działania [8].

Badania nad jakością życia dostarczają danych na temat sytuacji chorego, pozwalają dostrzec problemy, których doświadcza i podejmować działania ukierunkowane na ich rozwiązanie. Umożliwiają zatem optymalne planowanie i realizację opieki pielęgniarskiej oraz przygotowanie chorego do samoopieki. Przyczyniają się do podniesienia nie tylko jakości opieki nad pacjentem, ale także domen jakości jego życia. 


\section{Wnioski}

Wyniki przeprowadzonych badań umożliwiły wyciągnięcie następujących wniosków:

1. Wśród osób z rozpoznaną depresją kobiety istotnie lepiej niż mężczyźni oceniają dziedziny jakości życia: fizyczną, psychologiczną, środowiskową i relacji społecznych.

2. Osoby w wieku 25 do 45 lat nie różnią się istotnie w ocenach domen jakości życia od pacjentów w wieku 46 do 70 lat.

\section{Zalecenia dla praktyki pielęgniarskiej}

Działania na rzecz poprawy jakości życia pacjentów z depresją stanowią istotny element świadczeń realizowanych przez pielęgniarkę. Zmierzają one do zapewnienia choremu wsparcia i poczucia bezpieczeństwa. Pielęgniarka w relacjach z pacjentem i jego rodziną powinna wykazywać empatię, wrażliwość i cierpliwość. Tylko holistyczne postrzeganie problemów chorego stanowi gwarancję poprawy stanu zdrowia pacjenta, a tym samym optymalizuje jakość jego życia.

\section{Bibliografia/Bibliography:}

1. Nowak S. Metodologia badań społecznych. Wydawnictwo PWN, Warszawa 2010.

2. Kurpas D., Miturska H., Kaczmarek M. Podstawy psychiatrii dla studentów pielęgniarstwa. Wydawnictwo Continuo, Wrocław 2009.

3. Koszewska I., Święcicki Ł. Nie bój się lęku. Wydawnictwo Lekarskie PZWL, Warszawa 2008.

4. Gawlik O., Nowak J.. Zaburzenia rytmów biologicznych w depresji poszukiwanie nowych strategii terapeutycznych. Postępy Psychiatrii i Neurologii. 2006;15 (3): 171-178.

5. Wilczek-Rużyczka E. Komunikowanie się z chorym psychicznie. Wydawnictwo Czelej, Lublin 2007 
6. Ostrzyżek A. Jakość życia w chorobach przewlekłych. Probl Hig Epidemiol. 2008;89(4):467-470.

7. Trzebiatowski J. Jakość życia $\mathrm{w}$ perspektywie nauk społecznych i medycznych-systematyzacja ujęć definicyjnych. Hygeia Public Health. 2011;46(1):25-31.

8. Kowalik S. Pomiar jakości życia. Wydawnictwo AM, Poznań 2001.

9. Rosenthal M. Depresja. Wydawnictwo KDC, Warszawa 2002.

10. Łoza P., Parnowski T. Nowa depresja, nowe leczenie. Medical Education, Warszawa 2012.

11. Steiner M.,Yonkers K.: Depresja u kobiet. Via Medica, Gdańsk 1999.

12. Trojanowska A.: Znaczenie badań nad jakością życia w medycynie. Zdrowie Publiczne. 2011; 121(1): 99-103.

13. Kochman D.: Koncepcje teoretyczne jakości życia. Pielęgniarstwo Polskie. 2008; 1(27), 55-58. 